\title{
Performing English with a Postcolonial Accent: Ethnographic Narrativ es from Mexico
}

Received: 14-Apr-2013 / Accepted: 18-May-2013

A Clemente,M J Higgins. (2008) Performing English With A Postcolonial Accent: Ethnographic Narratives From Mexico. The Tufnell Press. 240 pages ISBN-10: 1872767877 ISBN-13: 9781872767871

Angeles Clemente and Michael Higgins is a textured portrait of Oaxacan students enrolled in a university English program (the Centro de Idiomas, or Centro). In it, the authors show us their students' relationship to widely-accepted notions of English ownership, English-speaker legitimacy, and the global spread of English. It is important that more professionals in the field of applied linguistics examine these relationships. Clemente and Higgins do so from an interdisciplinary, theoretical background without isolating the reader from outside those fields.

In the first part of this three-part text, anthropological terms and concepts are glossed in order to help the reader understand how the narratives that are collected in the middle of the book are discussed at its end. Domain-specific turns of phrase such as "ethnographic praxis", "the geopolitics of colonial difference" and "language ideologies in contact zones" are clarified before being employed. Salient here are Mary Louise Pratt (1991) and Suresh Canagrajah's "safe houses" (2004), Pratt's work, and that of Benedict Anderson (1991), on imagined communities and the center and the periphery of such places, as well as Adrian Holliday's "ghost of the native speaker" (2005). The Argentine semiotician Walter Mignolo factors heavily into Performing English, helping the authors unmask "coloniality disguised by the lights of modernity's progress" (2005). In fact, the included glossary is so helpful in making anthropological theory readily accessible, that Chapter 1 of Performing English serves well as a primer and partial introduction to the field of anthropological linguistics.

Chapter 2 then sets the stage for the narrativedriven, second part of the book, by giving accounts of two students who explain their admission and enrollment in the university. Before reading, I expected to learn about postcolonial language politics in Oaxaca, Mexico; a state whose population is politically outspoken and strongly indigenous. But the book eschews a discussion of Oaxacan politics in favor of focusing on its students and the methodology the authors use to understand and analyze their relationship with English language study. Each experience helps us to understand the common and the unique challenges students at the Centro face. These individual experiences begin to shape a larger context for the narratives.

Having provided the reader with a theoretical framework and a real-world context, the book proceeds to introduce its main actors in the first of three chapters that comprise its mid-section. Through biographical information and interactions with their peers and their studies, the reader learns how each student views herself or himself as an English speaker. Particularly reflective is the young man who feels isolated after returning to teach in his community, where he believes his English acquisition is an asset, but finds that instead, it isolates him socially.

In Part II, Chapters 3, 4, and 5, we witness student participants negotiating their language study and affirming their legitimacy as language community participants with each other, with faculty, and with the wider Oaxacan community. Some of the students specifically address notions of ownership as they explain their personal reasons for studying at the Centro. There are two notable examples from this part of the book that illustrate students advocating their claims to English. 
In the first example, several student social groups discuss when they use English among their group. One student claims he "[o]wns English as soon as he begins to use it." He and his peers not only use English; they manipulate it in unique and creative ways in their group. They cite switching to English when they don't want their parents to understand them and inventing bilingual nicknames for other students at the Centro. This code-switching is a linguistic phenomenon wherein language is enriched by performance on the periphery. It shows these cliches' heavy stakes in English as it combines with Spanish at the core of their social bonds. In another example from the same section, the authors include a lesson that two of the students give on vulgar language, most probably because they (the authors) have the same penchant for mischief-making (or "shit-disturbing" as they put it) that some of their students do. Mischief and expletives aside, this vignette shows these students' autonomy in curricular decision-making where they assert the relevance and appropriateness of certain cultural tokens.

The final chapter in Part II is perhaps the most revealing of student experience because these encounters take place outside the "safe house" of their university. Once graduates had established their own identities as English speakers, they had to assert these identities outside the relative insulation of the university. Some had to renegotiate these beliefs and advocate for themselves as English users. One young man struggles with his English-language identity as his status is elevated through various contract positions. A particularly harrowing encounter as a translator for the Mexican police during a narcotics bust causes him to profoundly re-examine his belief system and English-user identity.

In Part III, the authors revisit individual events of the narrative to situate them within theoretical frameworks. Especially applicable is the theme of safe houses, introduced by Pratt, where students who are on the "periphery" of a language community construct their own places to develop language identity. In
Canagarajah's further development of the theme, he writes "Safe houses nurture the dream of an alternative reality for students" and allow them to "Construct their own identities outside of the hegemony of the classroom (2004)." Canagarajah not only writes the forward for the present book; the aforementioned work practically begs for its publication. He implores colleagues to study other examples of student language identity development within their own safe space and subsequent negotiation of these identities in wider spheres. In reflecting on examples of safe houses from Chapter Four, the authors forge a challenge to centric views about the legitimacy of those on the periphery to participate in shaping language in the global community.

It is important to note how faithful the authors are to the students' voices in their narratives. This loyalty lends great authenticity to the text, and that authenticity makes these students' experience more relevant to readers in other contexts. The importance of acknowledging the power negotiations that occur with students of English is accentuated in this text. If practitioners examine their students' attitudes toward English, more meaningful study can occur in a wider-variety of contexts. Those unfamiliar with these postcolonial theoretical frameworks will find Performing English, as I did, an inspiring introduction, and veterans familiar with said frameworks will find it a much-needed link between theories. With Performing English, we have the ethnographic encounter Canagarajah called for, as well as a manual for local adoption in other postcolonial zones.

As the book is written in an interdisciplinary format, it should be commended for the clarity of methods, blending theory from applied linguistics, anthropology, semiotics, discourse analysis, and critical pedagogy. The text does not read like a practical handbook or theoretical research; it uses engaging ethnographic narrative. The accounts of students in the Centro explain theory in context. As educators, we are often more prepared than our students to question institutional structures. Yet these 
accounts put together the complex nature of the students' relationship with English without interference from the researchers.

The book lacks in-depth, critical discussion of current ideology at the core of the language teaching profession that delegitimizes the experiences we read about in Performing English. Such devaluation of the linguistic contribution of those on the periphery is glaring in textbooks that ignore those users and in teacher training that privileges education abroad. Past work by the authors broaches these topics. But a current, socio-political framework mentioning national language education reform could ingratiate the text further with postcolonial theorists. Current reforms in Mexico carry a curriculum and materials originating at the core (specifically, dominant commercial enterprise) and excluding the periphery. Curricular goals of the program encourage students to "be through" the English language, adopting cultural traditions of dominant cultures and native-like accents. Students from Clemente and Higgins's text tell us that they already "are" in the English language and that their experience in multiple languages allows them agency to choose cultural tokens relevant from the target culture.

Initiatives like the one outlined above are prolific; they are guided by neoliberal ideology and push an economic agenda. They are emblematic of Mignolo's precaution about "coloniality disguised by the lights of modernity's progress." Given the universality of such reforms, critical discussion and deconstruction of such agendas in the text is essential for a thorough understanding of the challenges facing participants on the periphery.

Language professionals should examine the work these professors have done in advocating their students' claims on English and view Performing English with a Postcolonial Accent as a text written for the applied linguistics professional community. If we each support our own students' similar claims, applied linguistics can evolve to break down hegemonic structures of language learning.

\section{References}

Anderson, B. (1991) Imagined communities, London: Verso Books.

Canagarajah, S. (2004) Subversive identities, pedagogical safe houses, and critical learning, in, Norton, B. \& Toohey, K. (Eds.) Critical Pedagogies and Language Learning. Cambridge, Cambridge: Cambridge University Press.

Holliday, A. (2005) The Struggle to Teach English as an International Language, Oxford: Oxford University Press.

Mignolo, W. (2005) Prophets Facing Sidewise: The Geopolitics of Knowledge and the Colonial Difference, Social Epistemology, 19 (1): 111-127.

Pratt, M. L. (1991) Arts in the Contact Zone, Profession, 91: 33-40.

LESLEY NEWMAN, has an MA in TESOL from the University of Arizona. She worked with the faculty of the Universidad Autonomo de Benito Juarez in Oaxaca, Mexico in 2012 as a US Fulbright Scholar. She is interested in SLA identity studies and developing critical thinking skills. Currently,she teaches in Danang, Vietnam. 